\title{
SOCIALIZATION ON HOW TO DEAL WITH HOAX INFORMATION TO JUNIOR HIGH SCHOOL STUDENTS IN OEBELO VILLAGE, KUPANG TENGAH - EAST NUSA TENGGARA
}

\author{
Franky $^{1 *}$, Thomas Budiman ${ }^{2}$ \\ ${ }^{1}$ Prof. Dr. Moestopo (Beragama) University \\ ${ }^{2}$ Bina Nusantara University \\ *franky@rehobot.org
}

\begin{abstract}
This community service activity was carried out to provide understanding as well as anticipation to teachers in Oebelo village, Kupang Tengah, Kupang, East Nusa Tenggara, Indonesia regarding news that contains false and misleading contents (hoax). Teachers who have more time with their students, are expected to transfer their understanding so that they will not easily believe unverified news. These understanding and anticipation were also delivered to junior high school students (grade VIII to IX) that in reality had started to know information technology - social media. The development of information technology - social media that has positive and negative impacts must be seen as important and urgent matter to be handled properly. This development should be directed towards improving the quality of human resources (human capital development) in this millennium era. However, in reality, even false news or messages have a detrimental effect on a person or community. Therefore, as the final result of this activity, two guidelines will be made; how to anticipate hoax news and how to utilize abundant information sources through the development of information technology, especially internet media. This is done as part of the effort to improve the quality of human resources.
\end{abstract}

Keywords: Hoax, social media, internet

\section{INTRODUCTION}

Information and communication technology has developed in a double exponential manner (Efron, 1986) after entering the $21^{\text {st }}$ century, marked by the expansion of all lines of human life with the advancement of information and communication technology. World communication that is no longer limited by space and time, 24/7 has become an inherent part of human life throughout the universe. Therefore, a term internet of things was formed (Farooq \& Waseem, 2015; Patel \& Patel, 2016; Zulhuda, 2016), which refers to the concept of connectedness between humans and humans, humans and machines, or machines and machines through internet technology. Internet technology (CohenAlmagor, 2011) $\square$ has revolutionized human ways and behavior in interacting with one another. The old patterns of communicating and interacting have dramatically been abandoned. Internet communication technology has provided an effective and efficient and up-to-date solution. Beginning in 1969, where the Department of Defense of the United States developed ARPANET as an internet networked computer. Tim Berners Lee developed new technology in the form of a global electronic accessible through the internet. The term world wide web (www) was introduced in 1990.

Indonesia started to be familiar with internet technology in 1990 (Astika, 2018) and PT Indo Internet (INDONET) was established as an internet service provider or commercial internet service in 1994. For additional information, data compiled through the bulletin of the $22^{\text {nd }}$ March 2018 edition of the Association of Indonesian Internet Service Provider (APJII) presented the results of a survey entitled "Indonesian Internet User Penetration and Behavior in 2017." The results of a collaboration survey with technopreneur mentioned that the penetration of internet user in Indonesia increased to 143.26 million people or equal to $54.7 \%$ of the national population. 


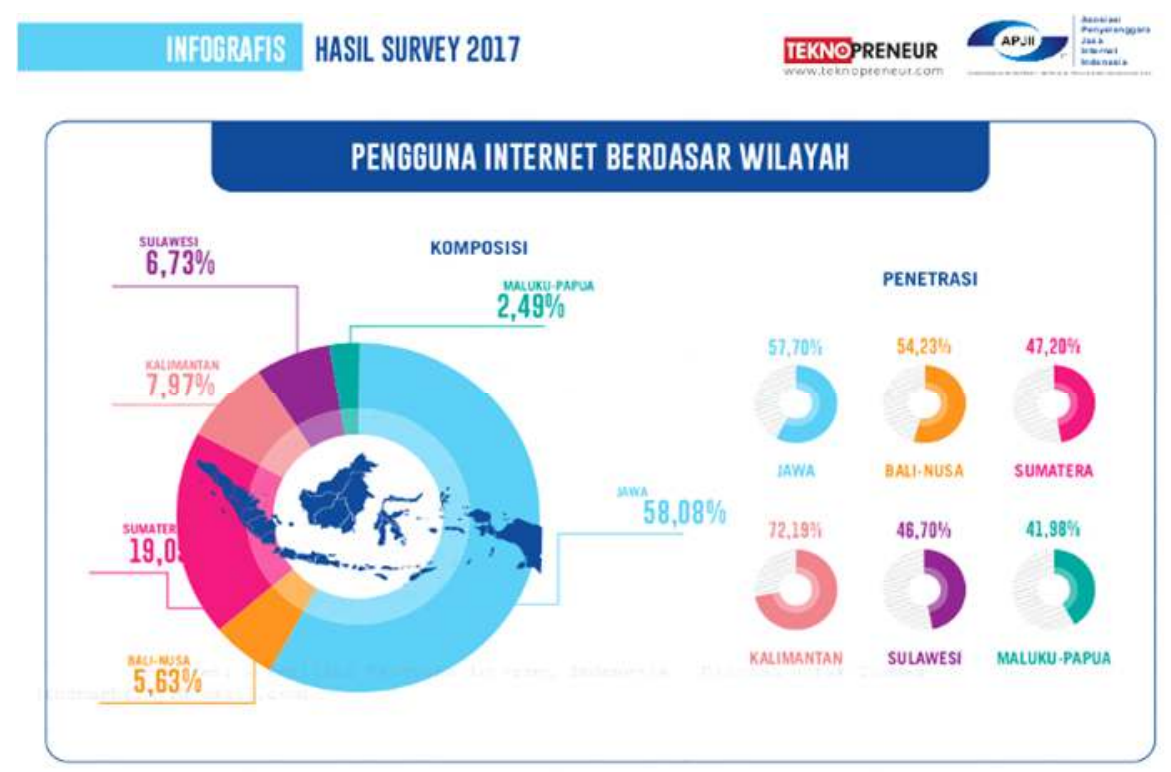

Figure 1. Internet Users by Region, source: (APJII, 2017)

The development of internet technology that has a positive, efficient and effective impact in various areas of life has driven economic, educational, health, social and cultural activities to increase significantly. The conventional system of world trade has been replaced by the power of internet technology. Efficient in terms of time, cost, communication, and coordination has become a powerful "medium of exchange" in the use of this internet technology.

The classic system of education in which students must be present in classes has been significantly replaced by flat screens and remote conversations with teachers. The mechanism of medical action that has to be handled directly by the hands of doctors has been replaced with robotic hands that can be moved remotely. Those are significant, systematic, and directed changes. However, in the midst of the positive advantages gained from the development of internet technology, it was found that there is a negative side (Hashem, 2015; Kavitha \& Bhuvaneshwari, 2016; Siddiqui \& Singh, 2016). To mention one, social media (Lusk, 2015). Social media refers to media or applications that allow users to create and share contents with others on a particular network. Some well-known social media include Facebook, Google+, Myface, Instagram, Linkedin, Pinterest, Snapchat, Twitter, Wechat, and Whatsapp. A number of surveys show that there has been a significant increase in social media users.

Hoax content ("What is hoax? - ANTARA News," 2017) which is disseminated through social media channels has made riot in the world. Spreading misleading false news may cause anxiety and panic, to the potential for conflict between countries. The hoax news included attacks on aliens to the earth (Orson Welles), alien autopsies (Ray Santili), the death of the legendary group BEATLES (Paul McCartney), the admission of Israel Professor to Islam (Moshe Sharon), Queen of the Austrian Emperor with hijab, and so on. Hoax news also hit Indonesia and many caused an atmosphere that was not conducive to the security of its citizens (Budiman, 2017). The hoax content is like the attack of ulama (Muslim Cyber Army), salt mixed with glass (unknown), online ojek vs. conventional transportation (unknown), and others.

Hoaxes that can trigger hatred, anger, and interpersonal, inter-group, and inter-ethnic revenge are very detrimental. Especially if the provocation that has a negative tone has become a promising business arena. A person or group that has social media information technology skills, who is capable of producing and distributing hoax content based on an 'order', is no longer a public secret. To achieve certain goals, a person or group uses fraudulent methods by spreading false news that is opposed to their opposition. Business competition cannot be separated from the hoax attacks that ultimately turn off the business of others. 


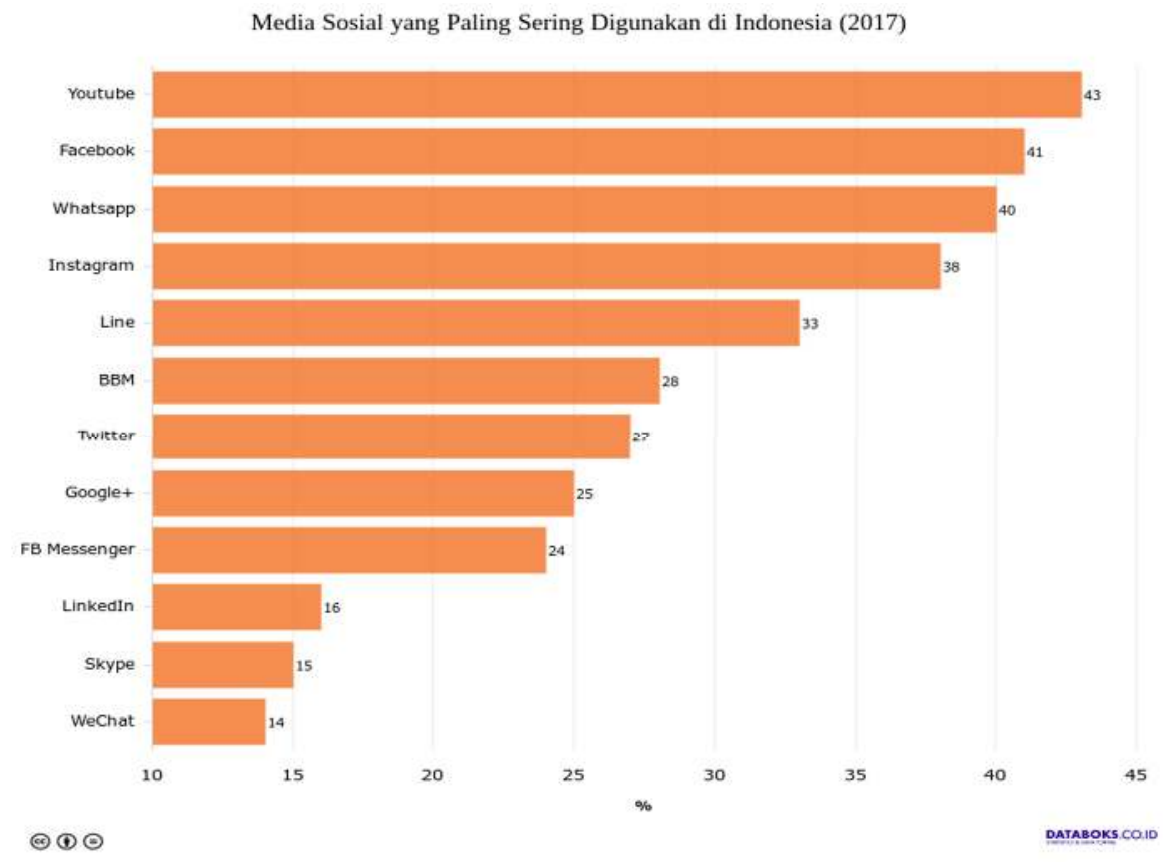

Figure 2. Popular Social Media in Indonesia 2017, source: (Katadata.co.id, 2017)

Based on the aforementioned matters, the paper and socialization activities for Indonesian people in general and the residents of ex-East Timor refugees in Oebelo village, Kupang, East Nusa Tenggara must be carried out. This activity is to anticipate unwanted events as early as possible related to news that is misleading or hoax. In fact, valuable sources of information through social media can be directed towards the development and improvement of human quality in this millennium era (Gomez Vasquez \& Soto Velez, 2011; Kavitha \& Bhuvaneshwari, 2016).

\section{METHOD}

This community service activity in Oebelo village, Kupang Tengah, East Nusa Tenggara was attended by students ranging from grades 7 to 9 of junior high school, and teachers. This activity was conducted on Tuesday, August 14, 2018, at 11.00 WITA. The activity themed: SOCIALIZATION ON DEALING WITH HOAX INFORMATION IN BUILDING HUMAN CAPITAL IN THE MILLENIUM ERA was divided into two sessions, teacher and students. This activity was carried out with the following methods: (1) Lecture, as a means of giving insights to the discussion participants regarding existing trends related to the development of information technology, especially communication media and social media. (2) A brief video screening of technological developments in life from time to time. (3) Questions and answers with the discussion participants, started with a survey of smartphone use by female students of Rehobot Oebelo Christian School.

This activity was attended by 22 elementary and junior high school teachers with details of 21 having cellular phones (smartphones) used for browsing, downloading, learning, music, games, watching, communication, chatting, social media, business and googling. The applications they use are WhatsApp, Facebook, Google, YouTube, Facebook, Telegram, and Instagram. The news that interests the teachers are: politics, family, business, education, entertainment, health, culinary, film, sports, corruption, science, and songs, with the topic: Ahok divorce ( $\mathrm{fb}$ ), getting prizes (sms, wa), the death of Rowan Atkinson ( $\mathrm{fb}$ ), the death of Jet Lee (fb), CPNS (fb), the death of Panji (google), Raffi Ahmad $(\mathrm{fb}$, youtube).

Junior high school students who took part in this activity were 71 people, consisting of 32 students in class VII, and 22 students in class IX. A total of 13 students have smartphones and 58 do not 
have one. The communication tool is used to phone, browsing subject matter, games, with upload applications of Facebook, Google, Google Maps, online games, Sniper 3D, Helix Jump, and Instagram.

\section{RESULT AND DISCUSSION}

The community service activity was conducted in Oebelo village, in the sub-district of Kupang Tengah, East Nusa Tenggara Province, Indonesia (LIPI, 2015). The village, which had approximately 400 heads of household, was inhabited by refugees during the 1998 East Timor referendum (BP Statistics, 2009; D.P. NTT, 2017). The main livelihoods of Oebelo villagers are as salt farmers, construction workers, and very few as civil servants. This activity was attended by Mrs. Jina Soares, S.Pd., as the Principal of Rehobot Christian Elementary School and her staff, Mrs. Prima Sabneno, S.Pd., as the Principal of Rehobot Christian Junior High School and her staff, as well as students grade 7 to 9 .

The purpose of socialization to the Oebelo villagers, especially to the school principals and teachers and students of Rehobot Christian Junior High School was expected to minimize the negative impact of hoax contents from the development of social media. From the results of this socialization, it was found that teachers and principals were very familiar with social media and its development (Hashem, 2015; Mingle, Adams, \& Adjei, 2016). It is proven that $96.15 \%$ of educators have smart devices that are connected to several social media applications. Facebook, Instagram, telegram, and WhatsApp are the favorite social media applications. In fact, there are two teachers who have more than 1,000 followers on their Instagram accounts (1,083 and 1,165 followers). Inevitably, news that has negative contents is very easy to find through these social media channels. Similar case happened in students who have been in junior high school. Some students are aware of social media and in average they understand what is meant by hoaxes.

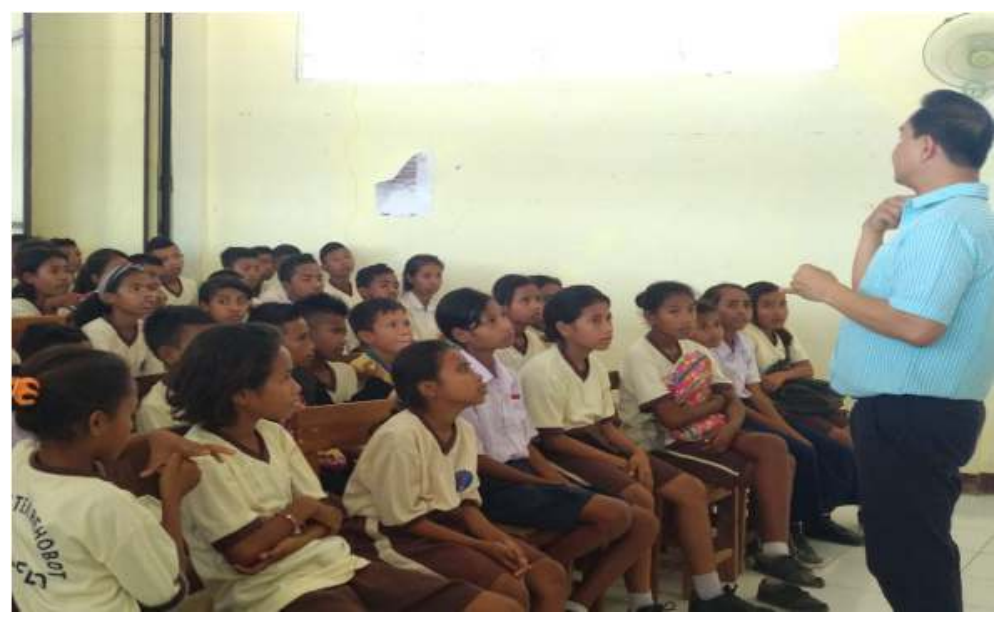

Figure 3. Socialization by Presenter to Female Junior High Students Grade 7-9

In carrying out this activity, there were several stages as follows: (1) Observation on internet user penetration in Oebelo village, Kupang Tengah, East Nusa Tenggara. (2) Socialization on hoaxes to Junior High Students Grades 7 - 9. (3) Discussion and questions and answers with students, including: 1. Ardin, $9^{\text {th }}$ grader, explained her understanding related to the definition of hoax, 2. Elizabeth, grade 8 student, explained her understanding of social media. The next activity was (4) socialization with the board of elementary and junior high school teachers regarding hoax news and its proper handling.

Based on this, socialization was carried out to anticipate the negative impact of hoax messages so that it is not only minimized or even eliminated. Instead, directing abundant sources of information through social media is a learning tool that can improve the quality of world-class human resources (Hashem, 2015). 


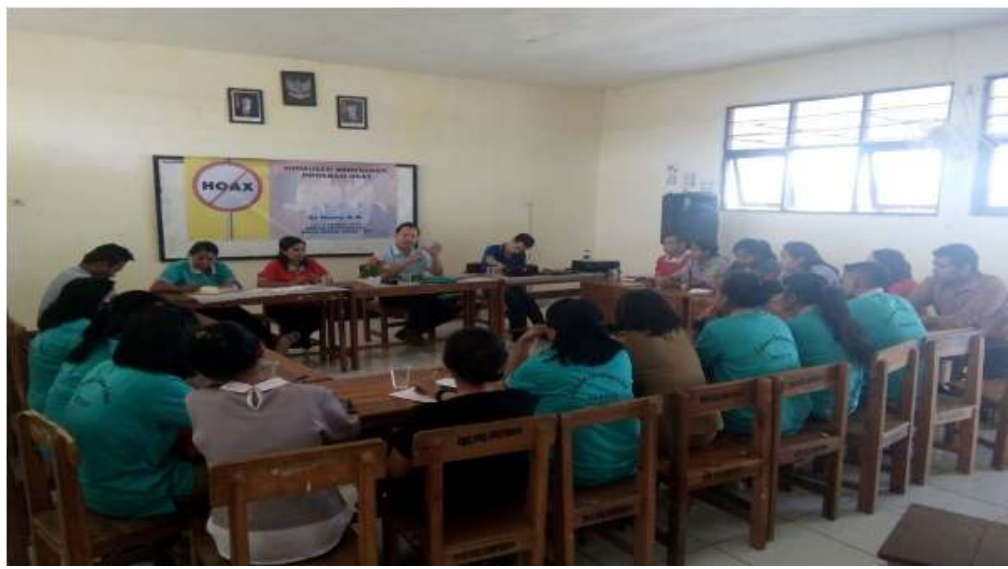

Figure 4. Socialization by Presenter to Rehobot Christian Elementary and Junior High School Teachers

\section{Guidance for anticipation in dealing with Hoax news}

There has been a lot of literature discussing steps to anticipate hoax contents on social media; through a range of seminars, training, symposiums, and so on. Like activities organized by the Ministry of Communication and Information through Mudamudigital. The government considered it important and urgent to educate teenagers and young people living in the millennial age so that they are smart in choosing and sorting the news contents that are appropriate for consumption (Kavitha \& Bhuvaneshwari, 2016; Okundia, 2016). Meanwhile, Septiaji Eko Nugroho as the Initiator of Indonesian Anti-Defamation Society (MAFINDO) and as the Chairman of Indonesian Antihoax Society explained that Indonesian people are very easily provoked by false news, especially relating to health and financial issues. Inevitably, thousands and even millions of people are often the victims of 'deceitful' investment. Even though Indonesian Government through KUHP Articles 310 and 311 and ITE Law (Kemenkumham, 2008; Law of RI 19, 2016) has given criminal threats to people, bodies, or groups that disseminate or provide bad information on the internet, fake contents regarding racial intolerance, hatred, threats, cyber-bullying, and slander still occur in social media channels. Therefore, on this occasion, several anticipatory measures were delivered to counter hoax news both to educators and students as follows: (1) Pay attention to the title of the article! If it has a provocative tone, it needs to be suspected as contents that contain hoax; (2) Cross check with other more credible news source such as cnn.com, kompas.com, detik.com, and others; (3) Check the domain or url for dubious information; (4) Check the images/photos/icon included; (5) Check the writer or uploader; (6) Have insight in internet (hoax buster).

It is expected that the presentation of the steps above can anticipate the development of news or messages containing hoaxes.

\section{Guidance for utilizing information source from Social Media}

The negative impact of social media seems to be a contrast which causes some people to be anti-social media. However, in reality, there is a positive side that can be utilized from social media (Siddiqui \& Singh, 2016). Expert staff of the Minister of Communication and Information in Technology, Herry Abdul Azis, said that the internet had expanded information further. In a matter of seconds, a message that is broadcast can be known by all people throughout the world. The improvement of the economic sector in the era of e-commerce has become the main attraction for new comers to have their business start-ups. Of course this can be accommodated through the development of internet communication technology, especially through social media.

Call it a South Korean singer, Psi who earned US \$ 5.9 million thanks to the "Gangnam Style" video that exploded on the world market via YouTube social media accounts. In addition, Rahmah Hayati, a student of communication science at a private university in Yogyakarta, sent a report published by Kompasiana, September 2017. Rahmah said that social media could be used as a medium for 
learning. For example, learning English in a self-taught way. Besides being more fun, learning through social media channels will train someone to have commitment and consistency to be independent.

Below is the guidance for utilizing information from social media that can improve one's quality: (1) Ask! Is the news important for improving my knowledge, competence and expertise? If 'yes', continue to the next point. If "no", ignore it and forget about the news!; (2) Classify according to competency, scientific, and skills needs. Of course, the information received is free of hoaxes; (3) Learn by adding other learning resources, such as literature, journals, and textbooks as an effort to scientifically verify and develop competencies, knowledge and skills: (4) Practice, practice and practice; (5) Keep up with the development of competence, knowledge, and skills through social media. Remember! Change is NECESSITY. Do not linger in the comfort zone; (6). You want to be an expert in competence, knowledge, and skills in your field? Share with and teach others so that the person has competence, knowledge, and skills like You!

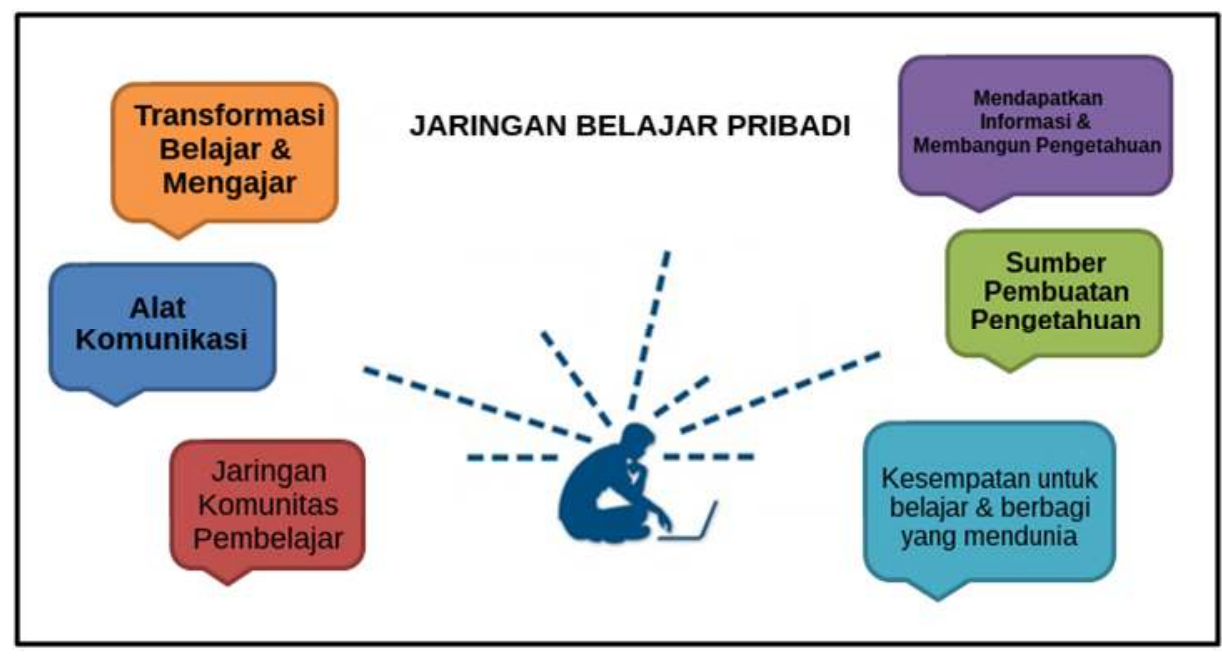

Figure 5. Benefits of Social media in Learning Process

This is the usefulness of the abundant source of information from social media that can be used to improve the quality of human resources. Indonesian people in general and residents of Oebelo village, Kupang, East Nusa Tenggara must view social media activities from a perspective that can bring benefits. Each phenomenon will produce two poles, positive and negative. For the main problem of the development of the world of social media information and internet communication that cannot be avoided, let alone be stopped, let us see and optimize the positive side for the development of Indonesia's human quality in the millennial era.

\section{CONCLUSION}

The development of information technology cannot be stopped. Various applications, games and social media are growing rapidly. So is with the news that follows in it, either the true ones or the false, or hoax ones. However, we are the ones who determine the type of news that is worth consuming by the mind. Full awareness and maturity is needed in interpreting the messages received through social media.

Use social media to gather materials that can enhance knowledge, competence, and skills in this millennial age. Keep up with the development and join in world-class communities that can provide new insights for improving human quality in the future.

\section{ACKNOWLEGEMENT}

Thank you to all parties who have supported the implementation of this activity, they are: Prof. Dr. Rudy Harjanto, M.Sn., Rector of UPDM (Beragama); Dr. Rajab Ritonga, M.Si., Head of Research and Community Service Institution of UPDM (Beragama); Prof. Dr. Paiman Rahardjo, M.Si., Director 
of Postgraduate Program of UPDM (Beragama); Dr. Rahayu, SE., MM., Head of Magister Management Department of UPDM (Beragama), and to all board of teachers in Rehobot Christian School of Oebelo, Kupang Tengah, East Nusa Tenggara.

\section{REFERENCES}

Apa itu hoax? (217). Antaranews. Retrieved from https://www.antaranews.com/berita/605171/apa-ituhoax

APJII. (2017). Penetrasi dam Perilaku Pengguna Internet Indonesia 2017. Asosiasi Penyelenggara Jasa Internet Indonesia. Jakarta. Retrieved from https://cdnreport.dailysocial.id/Laporan_Survei_APJII_v1_3.pdf

Astika, F. (2018). Internet Development in Indonesia: A Preview and Perception.

BP Statistik. (2009). Statistik Kota Kupang 2009. Jakarta: BPS

Budiman, A. (2017). Berita Bohong (Hoax) di Media Sosial dan Pembentukan Opini Publik. Jakarta: Pusat Penelitian Badan Keahlian DPR RI.

Cohen-Almagor, R. (2011). Internet History. International Journal of Technoethics, Vol.2(2): 20. https://doi.org/10.4018/jte.2011040104; https://www.igi-global.com/gateway/article/54755

Efron, B. (1986). Double Exponential Families and Their Use in Generalized Linear Regression. Journal of the American Statistical Association, Vol. 81(395): 709-721. https://doi.org/10.1080/01621459.1986.10478327; https://www.tandfonline.com/doi/abs/10.1080/01621459.1986.10478327

Farooq, M. U., \& Waseem, M. (2015). A Review on Internet of Things. International Journal of Computer Applications, Vol.113(1), 1-7. https://doi.org/10.5120/19787-1571

Gomez Vasquez, L. M., \& Soto Velez, I. (2011). Social Media as a Strategic Tool for Corporate, . Revista Internacional De Relaciones Públicas, Vol.2, 157-174. https://doi.org/10.5783/RIRP2-2011-09-157-174

El-Badawy, T. A., \& Hashem, Y. (2014). The impact of social media on the academic development of school students. International Journal of Business Administration, 6(1), 46.

Katadata.co.id. (2017). Ini Media Sosial Paling Populer di Indonesia - Databoks. Retrieved from https://databoks.katadata.co.id/datapublish/2018/02/01/media-sosial-apa-yang-paling-seringdigunakan-masyarakat-indonesia

Kavitha, \& Bhuvaneshwari. (2016). Impact of Social Media on Millennials - A Conceptual Study. Journal of Management Sciences and Technology, Vol. 4(1), 80-86. https://doi.org/10.13165/SMS-15-7-1-09

Kemenkumham. (2008). Undang-undang Republik Indonesia Nomor 11 Tahun 2008 Republik Indonesia tentang Informasi dan Transaksi Elektronik.

LIPI. (2015). Pengembangan Wilayah Nusa Tenggara Timur - Dari Perspektif Sosial: Permasalahan dan Kebijakan (1st ed.). Jakarta: LIPI Press. 
Lusk, B. (2015). Use of Social Media and its Impact on Academic Performance of Tertiary Institution Students: A Study of Students of Koforidua. Journal of Education and Practice, Vol. 6(6): 94101.

Mingle, J., Adams, M., \& Adjei, E. A. (2016). A Comparative Analysis of Social Media Usage and Academic Performance in Public and Private Senior High Schools. Journal of Education and Practice, Vol. 7(7), 13-22.

Okundia, R. A. (2016). Impact of Social Media on Student Academic Performance. University of Benin. https://doi.org/10.4018/JCIT.2016040103

Patel, K. K., \& Patel, S. M. (2016). Internet of Things-IOT: definition, characteristics, architecture, enabling technologies, application \& future challenges. International Journal of Engineering Science and Computing, Vol. 6(5): 6122-6131. https://doi.org/10.4010/2016.1482

Saraswati, Muninggar Sri. (2018). Social Media and the Political Campaign Industry in Indonesia. Jurnal Komunikasi Ikatan Sarjana Komunikasi Indonesia. Vol 3(1): 51-65. http://www.jurnaliski.or.id/index.php/jkiski/article/view/124/pdf

Siddiqui, S., \& Singh, T. (2016). Social Media its Impact with Positive and Negative Aspects. International Journal of Computer Applications Technology and Research, Vol. 5(2): 71-75. Retrieved from www.ijcat.com

Zulhuda, S. (2016). The Concept of Internet. South East Asia Journal of Contemporary Business, Economics and Law, 8 December 2015. 